\title{
Cataract and lens opacification in a wild toad Incilius leucomyos (Anura: Bufonidae)
}

\author{
TOM W. BROWN ${ }^{1,2}$ \\ ${ }^{1}$ Kanahau Utila Research and Conservation Facility, Isla de Utila, IB 34201, Honduras \\ ${ }^{2}$ University of Nottingham, School of Geography, England, UK, NG7 2RD, UK
}

Author e-mail: tom@kanahau.org

$T^{\text {he }}$

he toad Incilius leucomyos (McCranie \& Wilson, 2000)

is a little known endemic species that occurs in disjunct populations on the Atlantic slope of north-central Honduras at $0-1,600 \mathrm{~m}$ asl (Köhler, 2011). The natural habitats of this species are lowland and premontane broad-leaf wet forest; interposed by streams in which they reproduce. The IUCN Redlist classifies I. leucomyos as Endangered (Wilson \& Cruz, 2004) owing to its restricted ecological distribution and the rising threats of deforestation and land-use change in Honduras (Wilson \& McCranie, 2004). The following note reports the case of an in situ adult I. leucomyos that was blind in one eye. Diagnosed pragmatically as a unilateral cataract, this observation is noteworthy as few accounts are available for ocular abnormalities in wild amphibians.

On the 2nd September 2015, 20.14 h, a sub-adult I. leucomyos was encountered in a privately protected area of premontane rainforest at Omega Tours Eco-Jungle Lodge, in the region of Pico Bonito National Park, La Cieba, Honduras (GPS [DMM] 15.731744, -86.730381). The individual was one of numerous (mostly adult) toads located active and calling on the surface of leaf-litter besides a trickling stream in closed canopy forest - presumably aggregating for reproduction. Upon observing one individual by flashlight, it was immediately apparent that the pupil of the left eye was cloudy and opaque, which under artificial light reflected back a smoky bluish-white (Fig. 1). The left eye appeared more dilated than the right, and opacity seemed concentrated on the inner lens, instead of across the outer cornea or in the aqueous chamber. The reactions of the toad when inspected suggest that the left eye was partially or completely blind; though, despite its ailment, the individual appeared to be in good health and behaving normally. Identification of the individual and other surrounding toads as I. leucomyos, was established by the presence of orange flecking on the dorsal flanks and toes and black-spot patterning on the dorsum. These basic descriptive features in combination with morphology (Köhler, 2011) differentiate I. leucomyos from its widespread and generalist congener Incilius valliceps; both species occur in the region of Pico Bonito National Park (McCranie \& Solis, 2014). The individual was photographed but its gender was not determined.

Cataract is a clouding of the eye's lens that can cause visual impairment and blindness. It can affect one or both eyes (unilateral or bilateral), and each case can develop differently with regards to size, morphology and degree of opacity. It can range from a small white dot on the anterior capsule to total opacity of the lens (Kalantan, 2012). Anurans are highly dependent upon vision for food acquisition and predator avoidance, and consequently any impairment to the optical or neural tissues of the eye, may reduce individual survival rates (Fite et al., 1998). Perhaps for that reason, cataracts are a rarely documented ailment in wild anurans.

Most literature refers to amphibian ocular abnormalities in veterinary cases or optical studies of captive frogs and toads (Shilton et al., 2001; Kilburn et al., 2019; Rosenthal et al., 2008). Corneal lesions, scarring, fibrosis, opacity, keratitis,
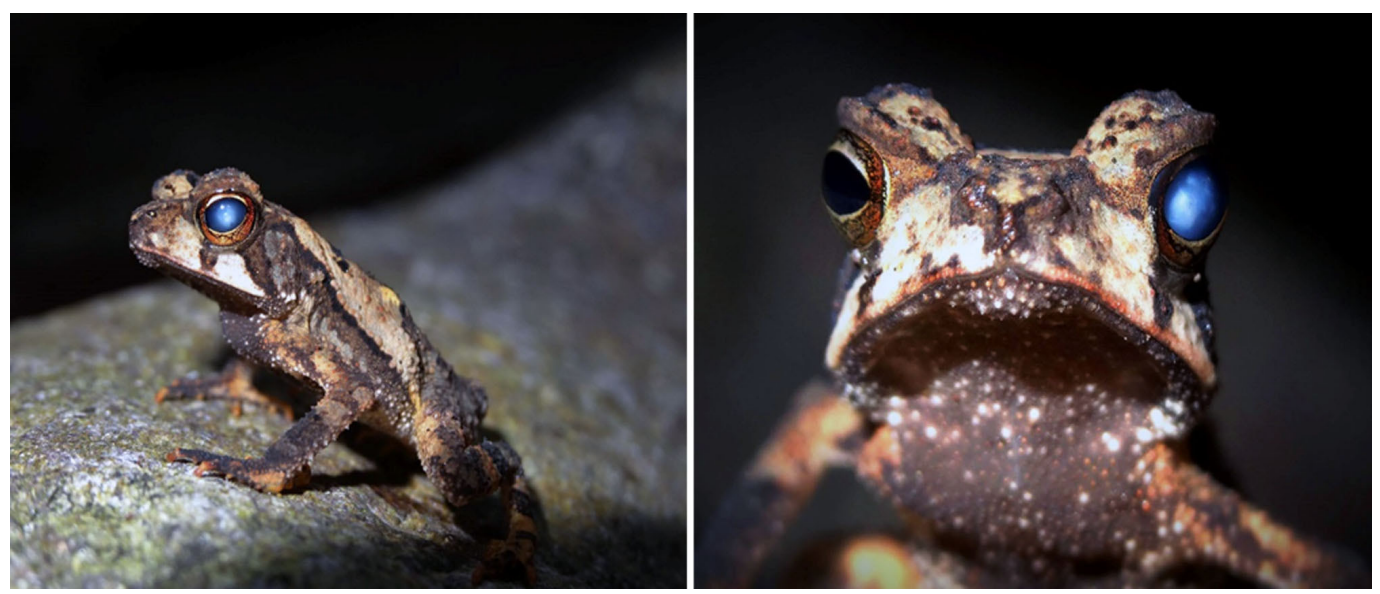

Figure 1. Photographs taken in the field of a sub-adult of the toad I. leucomyos, showing a unilateral cataract and lens opacity in the left eye 
lipidosis and interstitial cholesterol or lipid keratophagy, are all eye conditions typical of older captive amphibians fed high lipid-rich insect diets (Shilton et al., 2001; Lock, 2017; Russel et al., 1990). Dietary derived ocular impairment seem unlikely to progress under natural circumstances, as a wild amphibian's prey is not cholesterol rich (Lock, 2017) and amphibians might not survive long once developing visual impairment. Moreover, these conditions differ diagnostically from cataracts of the eye lens, in that they instead cause opacity in the outer layer of the cornea. For that reason, the information and visual inspection of this I. leucomyos case concludes unilateral cataract as the most probable diagnosis, as no evidence suggested corneal lipid deposition or otherwise damage to the cornea (Shilton et al., 2001; Lock, 2017). Prior studies associate cataracts in amphibians with old age (Rosenthal et al., 2008; Kilburn et al., 2019), but they might also occur due to trauma or radiation exposure (Popov et al., 1963; Worgul \& Rothstein, 1975; Hayden et al., 1980; Worgul et al., 1982) and develop during larval stages. Given the individual was not fully-grown or of old age, perhaps the cataract development was of genetic origin during an earlier developmental stage (Shiels \& Hejtmancik, 2007).

The cause and severity of the cataract in this case are only subjects of speculation, as it was not possible to collect the specimen for detail ophthalmological investigation. Nevertheless, this observation of I. leucomyos attests to the occasional presence and survival of individuals with ocular anomalies in nature.

\section{ACKNOWLEDGMENTS}

I would like to thank the owners of Omega Tours Eco-Jungle Lodge for accommodating my herping antics when visiting. Special thanks go to José Mario Solis for confirming the species identification of I. leucomyos by photograph and the Mesoamerican and Caribbean Network for the Conservation of Amphibians and Reptiles (Red MesoHerp Network) for their support.

\section{REFERENCES}

Fite, K.V., Blaustein, A., Bengston, L. \& Hewitt, H.E. (1998). Evidence of Retinal Light Damage in Rana cascadae: A Declining Amphibian Species. Copeia 1998: 906-914.

Hayden, J.H., Rothstein, H., Worgul, B.V. \& Merriam, Jr. G.R. (1980). Hypophysectomy exerts a radioprotective effect on frog lens. Experientia 36: 116-8. doi: 10.1007/ bf02004009

Kalantan, H. (2012). Posterior polar cataract: A review. Saudi Journal of Ophthalmology: Official Journal of the Saudi Ophthalmological Society 26 (1): 41-49. doi:10.1016/j. sjopt.2011.05.001

Kilburn, J.J., Bronson, E., Shaw, G.C., Labelle, P. \& Weigt, A. (2019). Phacoemulsification in an American Toad (Anaxyrus americanus). Journal of Herpetological Medicine and Surgery 29 (1-2): 17-20.
Köhler, G. (2011). Amphibians of Central America. Herpeton, Verlag Elke Köhler, Offenbach, Germany, 379 pp.

Lock, B. (2017). Corneal Lipidosis / Xanthomatosis in Amphibians. Veterinary Information Network, Inc. https:// veterinarypartner.vin. $\mathrm{com} / \mathrm{doc} /$ ?id=7996856\& $\mathrm{pid}=19239$ (accessed July 2019)

McCranie, J. R. \& Wilson, L.D. (2000). A new species of highcrested toad of the Bufo valliceps group from northcentral Honduras. Journal of Herpetology 34: 21-31.

McCranie, J.R. \& Solis, J.M. (2013). Additions to the amphibians and reptiles of Parque Nacional Pico Bonito, Honduras, with an updated nomenclatural list. Herpetology Notes 6: 239-243.

Popov, V.V., Goliochenkov, V.A. \& Farberov, A.I. 1963. Two components in the development of ray cataract in frogs. Nature 199: 1109-1110.

Rosenthal, K.L., Forbes, N.A., Frye, F.L. \& Lewbart, G.A. (2008). Rapid Review of Exotic Animal Medicine and Husbandry: Pet Mammals, Birds, Reptiles, Amphibians and Fish. CRC Press: Manson Publishing/The Veterinary Press. London, UK, 320 pp.

Russell, W., Edwards, D., Stair, E., \& Hubner, D. (1990). Corneal lipidosis, disseminated xanthomatosis, and hypercholesterolemia in Cuban tree frogs (Osteopilus septentrionalis). Journal of Zoo and Wildlife Medicine 21: 99-104.

Shiels, A. \& Hejtmancik, J.F. (2007). Genetic origins of cataract. Archives of Ophthalmology 125:165-173. doi:10.1001/ archopht.125.2.165

Shilton, C., Smith, D., Crawshaw, G., Valdes, E., Keller, C., Maguire, G., Connelly, P. \& Atkinson, J. (2001). Corneal lipid deposition in Cuban tree frogs (Osteopilus septentrionalis) and its relationship to serum lipids: An experimental study. Journal of Zoo and Wildlife Medicine 32: 305-19.

Williams, D.L \& Whitaker, B.R. (1994). The amphibian eye: A clinical review. Journal of Zoo and Wildlife Medicine 25: 18-28.

Wilson, L. D., \& McCranie, J. R. (2004). The conservation status of the herpetofauna of Honduras. Amphibian \& Reptile Conservation 3: 6-33. doi:10.1514/journal. arc.0000012

Wilson, L.D. \& Cruz, G. (2004). Incilius leucomyos. The IUCN Red List of Threatened Species 2004: e.T54690A11175905. http://dx.doi.org/10.2305/IUCN.UK.2004.RLTS. T54690A11175905.en. (accessed October 2019.

Worgul, B.V. \& Rothstein, H. (1975). Radiation Cataract and Mitosis. Ophthalmicic Research 7: 21-32. doi: 10.1159/000264731

Worgul, B.V., Rothstein, H., Medvedovsky C., Merriam, Jr. G.R. \& Wilson, M.A. (1982). Radiation cataractogenesis in the amphibian lens. Ophthalmic Research 14: 73-82. doi: 10.1159/000265177

Accepted: 12 October 2019 